\title{
Molecular analysis of HIF activation as a potential biomarker for adverse reaction to metal debris (ARMD) in tissue and blood samples
}

\author{
Agata Nyga $\mathbb{D}^{1,2}$ Alister Hart, $^{3}$ Teresa D. Tetley ${ }^{1}$ \\ ${ }^{1}$ National Heart \& Lung Institute, Imperial College London, London, UK \\ ${ }^{2}$ Institute for Bioengineering of Catalonia, Barcelona, Spain \\ ${ }^{3}$ Institute of Orthopaedics \& Musculoskeletal Science, Royal National Orthopaedic Hospital, University College London, \\ Stanmore, UK
}

Received 25 October 2017; revised 14 June 2018; accepted 12 August 2018

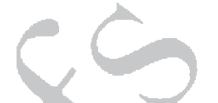

Published online 00 Month 2018 in Wiley Online Library (wileyonlinelibrary.com). DOI: 10.1002/jbmb.34227

Abstract: We aimed to find a biomarker for patients with adverse reaction to metal debris (ARMD) due to a metal-onmetal (MoM) hip implant. First, we compared molecular markers of hypoxia-inducible factor (HIF) pathway activation (BNIP3, GLUT1, HO1, VEGF, and HIF1A) and inflammatory response (IL1B and COX2) in tissue from patients undergoing revision of MoM hip implant with tissue from patients undergoing primary hip replacement (PHR). Second, we compared blood levels of the above molecular markers and additional inflammatory markers: TNFA, IL18, CASPASE1, $N F K B$ or $I K B$, and TLR1-4 mRNA in patients with non-failed MoM hips. We report the presence of increased expression of HIF-target genes in the periprosthetic tissue in MoM patients when compared to the PHR group. This suggests HIF pathway activation due to MoM debris and the potential of using HIF targets as a predictor of failure. Analysis of blood samples from nonoverlapping, nonfailed, MoM group showed significantly higher expression of COX2 mRNA and significant correlations between HIF1A and GLUT1 mRNA expressions, and between HIF1A mRNA and selection of inflammatory genes, including IL18,IKB, TLR1, and TLR4. HIF pathway activation in the periprosthetic tissue biopsies of patients with hip replacements may represent the first biomarker to identify early ARMD. Further studies investigating blood biomarkers could also prove beneficial in detecting ARMD that could lead to an early intervention and improved patient outcome after hip revision surgery. (C) 2018 Wiley Periodicals, Inc. J Biomed Mater Res B Part B: 00B: 000$000,2018$.

Key Words: MoM, cobalt-chromium, inflammation, hypoxiainducible factor pathway

How to cite this article: Nyga A, Hart A, Tetley TD. 2018. Molecular analysis of HIF activation as a potential biomarker for adverse reaction to metal debris (ARMD) in tissue and blood samples. J Biomed Mater Res B Part B 2018:9999:9999:1-11.

\section{INTRODUCTION}

Adverse reaction to metal debris (ARMD) in patients with hip implants is a histological diagnosis with an evidence of aseptic lymphocyte-dominated vasculitis-associated lesions containing lymphocytes ${ }^{1}$ and macrophages. ${ }^{2}$ The clinical suspicion of ARMD is raised by hip pain, cross-sectional imaging showing pseudotumors and blood cobalt levels above $4 \mu \mathrm{g} /$ L. ${ }^{3}$ Earlier and more certain diagnosis of ARMD would enable earlier revision surgery and preservation of muscle and bone, leading to improved patient outcomes. A blood or tissue biomarker for ARMD is our best chance of early diagnosis.

There are a variety of potential biomarkers for ARMD. The response to metals in patients with metal-on-metal (MoM) hip implants was reported to be driven by the $\mathrm{T}$ helper (Th1) cells dominated lymphocyte reactivity. ${ }^{4,5}$ This response is characterized by an increased expression of inflammatory markers, such as chemokine receptors (CXCR4, CXCL8, CXCL2), while expression of tumor necrosis factor (TNF) $\alpha$, receptor activator of nuclear factor kappa-B and its ligand are unchanged. ${ }^{6}$ However, the lymphocyte response occurs at a late stage of the adverse response, when necrotic tissues and macrophages containing the metallic nanoparticles are already present. $^{7}$ MoM synovial tissue was shown to be also positive for hypoxiainducible factor (HIF)-1 $\alpha$ protein, which was not found in the synovial tissue from patients with metal-onpolyethylene (MoP) hip implants. ${ }^{8}$ Furthermore, we have shown previously that cobalt toxicity is driven through activation of hypoxia pathway. ${ }^{9}$ Could HIF pathway activation by MoM wear debris play a significant role in the mechanism of the ARMD? We hypothesized that the MoM wear debris-induced HIF activation can be detected in the tissues or blood of patients with MoM. 
During HIF pathway activation, a series of genes responsible for various cellular responses are upregulated. They are responsible for cell metabolism (e.g., glucose transporters, such as GLUT1), cell protection (e.g., heme oxygenase, and HO-1), angiogenesis (e.g., vascular endothelial cell growth factor [VEGF]), cell death and survival (e.g., BNIP3). These markers could be measured in the blood and tissue. In this study, we analyzed both tissue and blood samples from control and MoM groups to identify HIF pathway activation gene expression markers, as a potential biomarker for ARMD.

\section{MATERIALS AND METHODS}

\section{Samples collection}

Ethics approval and patient selection. Ethics approval [07/Q0401/25] and patient consent was obtained for the use of tissue samples (synovial membranes) removed during surgery and blood samples collected in an outpatient clinic. Tissue samples were obtained from patients undergoing either a primary hip replacement (PHR group, $n=7$ ) surgery or a revision surgery (MoM tissue group, $n=12$, implantation time 3-4 years, implant types: Hip Resurfacing System, Large-diameter Total Hip Arthroplasty, Mitch Total Hip Replacement). Patients with unilateral or bilateral total hip arthroplasty were included in this study. For MoM group, patients with implants made of components other than MoM, such as metal-onceramic, were not included. The selection criteria for failed MoM included unexplained pain or high cobalt and chromium levels in the blood and serum. The exclusion criteria were infection, mechanical instability, or prosthesis malalignment.

Blood samples were obtained from second, nonoverlapping, group of patients with MoM hip implant during regular clinic appointments (MoM blood group, $n=16$, implantation time 3-14 years, implant types: Birmingham Hip Resurfacing System, Cormet hip resurfacing, Mitch Total Hip Replacement) and not scheduled for immediate revision surgery. All collected specimens were anonymized. For healthy volunteers' blood samples (control group, $n=8$ ), ethics approval [13/LO/1831] and consent was obtained. The healthy volunteers did not have any

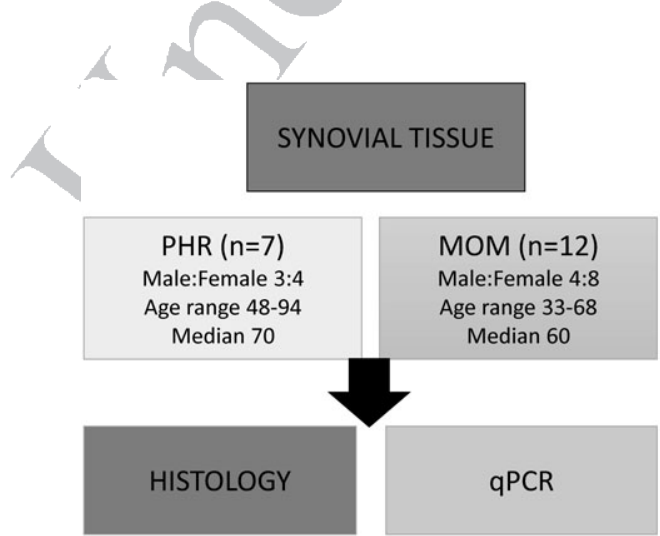

FIGURE 1. Study design. Synovial tissue was obtained from patients undergoing primary hip replacement (PHR group) or revision for metal-onmetal hip implant (MoM group). Blood samples were obtained from patients with MoM group or healthy volunteers (Healthy/Control group). orthopedic implant nor required one at the time of sample collection. Study design is presented in Figure 1.

Collection and storage. For tissue samples, two specimens per patient were obtained. First tissue specimen was used for histological analysis and was stored in 10\% neutral buffered formalin (CellPath, UK) at room temperature (RT). The second tissue specimen was used for RNA investigation and was stored in RNAlater (Sigma, UK) at $-20^{\circ} \mathrm{C}$ and used within 1 week. Each tissue size was on average $2 \mathrm{~cm} \times 1 \mathrm{~cm} \times 1 \mathrm{~cm}$.

For blood samples, $3 \mathrm{~mL}$ of blood was drawn directly into a Tempus ${ }^{\mathrm{TM}}$ Blood RNA Tube (two tubes per person, ThermoFisher, UK) and shaken vigorously to mix with the stabilizing reagent $(6 \mathrm{~mL})$. Samples were stored at $4^{\circ} \mathrm{C}$ until further use (up to 5 days).

\section{Tissue homogenization}

Tissues were removed from the RNAlater and cut into smaller pieces between 50 and $100 \mathrm{mg}$. A volume of $100 \mathrm{mg}$ of tissues was placed in $1 \mathrm{~mL}$ of RNA Bee (Amsbio, UK) and were homogenized using a tissue homogenizer (IKA-UltraTurrax $^{\circledR} \mathrm{T}$ 8, IKA ${ }^{\circledR}$-Werke GMBH \& CO.KG, Germany) for approximately $45 \mathrm{~s}$ on ice (three tissue homogenates per patient). Samples were centrifuged for $3 \mathrm{~min}$ at $12,000 \mathrm{~g}$ at $4^{\circ} \mathrm{C}$ and supernatants were used for RNA extraction.

\section{Gene expression}

RNA extraction. Tissue supernatants were mixed with chloroform and the homogenate was centrifuged for $15 \mathrm{~min}$ at $4^{\circ} \mathrm{C}$ at $12,000 \mathrm{~g}$. RNA in the clear upper phase was transferred into a new microtube $(\sim 500 \mu \mathrm{L})$, mixed with an equal volume of isopropanol, and incubated at RT for $30 \mathrm{~min}$. Following centrifugation, the RNA pellet was washed in $75 \%$ ethanol, centrifuged and air dried. The RNA pellet was dissolved in $20 \mu \mathrm{L}$ of diethyl pyrocarbonate (DEPC)-treated $\mathrm{H}_{2} \mathrm{O}$, vortexed and incubated for $30 \mathrm{~min}$ on ice. RNA samples were stored at $-80^{\circ} \mathrm{C}$ until further analysis.

For blood, total RNA was extracted using a Tempus ${ }^{\mathrm{TM}}$ Spin RNA isolation reagent kit (ThermoFisher) according to the manufacturer's instruction. Briefly, stabilized blood (total $9 \mathrm{~mL}$ ) was transferred to a $50 \mathrm{~mL}$ tube, diluted with $3 \mathrm{~mL}$ of phosphate buffered saline (PBS; $\mathrm{Ca}^{2+} / \mathrm{Mg}^{2+}$ free),

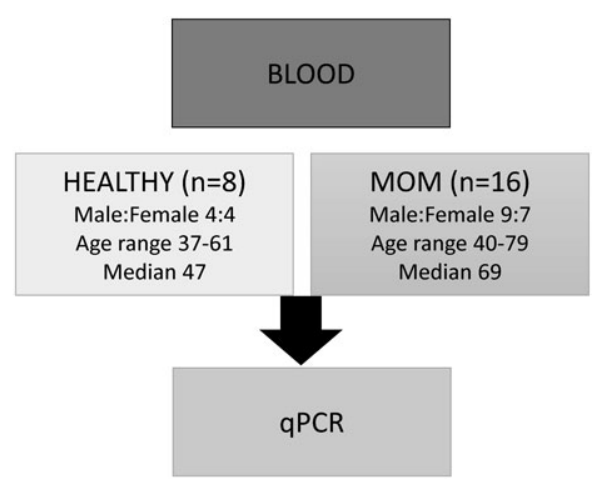


vortexed and centrifuged at $3,000 \mathrm{~g}$ for $30 \mathrm{~min}$ at $4{ }^{\circ} \mathrm{C}$. Supernatant was poured off and tubes were placed gently upside down for $1 \mathrm{~min}$ on an absorbent paper. The RNA pellet was mixed in $400 \mu \mathrm{L}$ of RNA purification resuspension solution on ice. RNA was filtered through washes with RNA purification wash solution 1 and RNA purification wash solution 2 using a purification filter/collection tube. Nucleic acid purification elution was used to elute RNA from the column membranes and the RNA eluate was stored at $-80^{\circ} \mathrm{C}$ until further use.

RNA quantification and cDNA synthesis. The RNA was quantified using a micro-volume spectrophotometer (NanoDrop ${ }^{\circledR}$ 1000, ThermoScientific) and associated software (NanoDrop ${ }^{\circledR}$ ND-1000 version 3.7). RNA purity was assessed by calculating ratio between absorbance (Abs) at 260 and $280 \mathrm{~nm}$. The RNA sample was considered pure when the Abs260/Abs280 ratio was 1.9-2.0.

For RNA extracted from tissues, cDNA synthesis was catalyzed using random primers $(500 \mu \mathrm{g} / \mathrm{mL}, 1: 60$ in DEPC-treated $\mathrm{H}_{2} \mathrm{O}$, Promega, UK). A volume of $500 \mathrm{ng}$ of purified RNA was placed in a PCR tube along with $1 \mu \mathrm{L}$ of random primers and DEPC-treated $\mathrm{H}_{2} \mathrm{O}$ to a total volume of $12 \mu \mathrm{L}$. The sample was incubated for $10 \mathrm{~min}$ at $72^{\circ} \mathrm{C}$ in a thermocycler ( $\mathrm{T}$ Gradient Thermoblock, Thistle Scientific, UK). After incubation, $8 \mu \mathrm{L}$ of Master Mix ( $4 \mu \mathrm{L}$ DEPCtreated $\mathrm{H}_{2} \mathrm{O} ; 1 \mu \mathrm{L}$ deoxyribonucleotide triphosphate (dNTPs); $1 \mu \mathrm{L}$ RNAsin ${ }^{\circledR}$ Ribonuclease inhibitor; $0.5 \mu \mathrm{L}$ Moloney Murine Leukemia Virus Reverse Transcriptase, RNase H minus, Point Mutant (M-MLV RT [H-]); $1.5 \mu \mathrm{L} 5 \mathrm{X}$ buffer; Promega) was added to the sample and it was further incubated for $10 \mathrm{~min}$ at $25^{\circ} \mathrm{C}$, for $60 \mathrm{~min}$ at $42^{\circ} \mathrm{C}$, and for $15 \mathrm{~min}$ at $70^{\circ} \mathrm{C}$. Synthesized cDNA was diluted in $80 \mu \mathrm{L}$ of double-distilled (dd) $\mathrm{H}_{2} \mathrm{O}$.

For RNA extracted from blood, 1000 ng of RNA was used to synthesize cDNA using a High-Capacity cDNA Reverse Transcription Kit (Applied Biosystems, ThermoFisher), according to the manufacturer's instructions. Briefly, $10 \mu \mathrm{L}$ of RNA was mixed with $10 \mu \mathrm{L}$ of Master Mix $(2 \mu \mathrm{L}$ of 10X RT buffer, $2 \mu \mathrm{L}$ of 10X RT random primers, $1 \mu \mathrm{L}$ of MultiScribe Reverse Transcriptase [50 U/ $\mu \mathrm{L}]$, and $0.8 \mu \mathrm{L}$ of $25 \mathrm{X}$ dNTP Mix [100 mM] in DEPC-treated $\mathrm{H}_{2} \mathrm{O}$ ) on ice in individual PCR tubes. PCR was performed in a thermocycler (MultiGene, Labnet International, Edison, NJ) in four steps: Step 1 of $10 \mathrm{~min}$ at $25^{\circ} \mathrm{C}$, Step 2 of $120 \mathrm{~min}$ at $37^{\circ} \mathrm{C}$, Step 3 of $5 \mathrm{~min}$ at $85^{\circ} \mathrm{C}$, and Step 4 of cooling down at $4^{\circ} \mathrm{C}$. cDNA samples were stored at $-20^{\circ} \mathrm{C}$ until further use. run for 30 cycles, while all other genes (Table I) for 45 cycles. Each cycle consisted of three stages: a denaturing step $\left(95^{\circ} \mathrm{C}\right.$ for $\left.10 \mathrm{~s}\right)$, an annealing step $\left(60^{\circ} \mathrm{C}\right.$ for $\left.15 \mathrm{~s}\right)$, and an elongation step $\left(72^{\circ} \mathrm{C}\right.$ for $\left.20 \mathrm{~s}\right)$.

For blood samples, primers (KiCqStart ${ }^{\mathrm{TM}} \mathrm{SYBR}^{\circledR}$ Green, KSPQ12012, Sigma; Table II) were diluted in DEPC-treated $\mathrm{H}_{2} \mathrm{O}$ at a concentration of $100 \mu \mathrm{M}$ and the primer mix was prepared by a 10-fold dilution of both the forward and reverse primers in DEPC-treated $\mathrm{H}_{2} \mathrm{O}$ (final $10 \mu \mathrm{M}$ concentration of each primer). For the reaction, $4 \mu \mathrm{L}$ of cDNA (giving a final concentration of $10 \mathrm{ng} / \mu \mathrm{L}$ of RNA) was pipetted into a 96-well reaction plate (MicroAMPтм Optical, Applied Biosystems) together with $16 \mu \mathrm{L}$ of Master Mix $(10 \mu \mathrm{L}$ SYBR $^{\circledR}$ Green Jumpstart ${ }^{\mathrm{TM}}$ Taq Ready Mix, $1.8 \mu \mathrm{L}$ primer mix, $4.2 \mu \mathrm{L}$ DEPC-treated $\mathrm{H}_{2} \mathrm{O}$ ). The run was performed on a PCR machine (Applied Biosystems ${ }^{\circledR} 7500$ Fast Real-Time PCR System) using 7500 Software (version 2.0.6). Each run was performed for 40 cycles and consisted of $50^{\circ} \mathrm{C}$ for $20 \mathrm{~s}, 95^{\circ} \mathrm{C}$ for $10 \mathrm{~min}$, and a cycling stage of $95^{\circ} \mathrm{C}$ for $15 \mathrm{~s}$ followed by $60^{\circ} \mathrm{C}$ for $1 \mathrm{~min}$. The house-keeping genes used included: $\beta$-actin, GAPDH, B2M, HPRT1, and RPL13A.

Three replicate reactions were run for each cDNA sample. At the end of each run a melt analysis was performed to confirm presence of one product. The $2^{-\Delta \Delta \mathrm{Ct}}$ model was used to analyze the qPCR results.

Primer efficiency and validation. To use the $2^{-\Delta \Delta \mathrm{Ct}}$ model to analyze the qPCR results, the amplification efficiency of primers must be approximately equal. ${ }^{10}$ Primer amplification efficiency was measured as a five-fold dilution series with the average Ct calculated from duplicates for each gene. The $\mathrm{Ct}$ values were then used to plot log cDNA versus $\mathrm{Ct}$ values to determine amplification value and reaction efficiency.

The following equations were used:

Amplification value $=10^{[-1 / \text { slope }]}$.

Reaction efficiency $=\left[10^{[-1 / \text { slope }]}\right]-1$.

A slope of value -3.322 gives a reaction efficiency of 1 , which indicates $100 \%$ primer efficiency. To use the $2^{-\Delta \Delta \mathrm{Ct}}$ model, we selected primers of efficiency between 92 and 108\% (slope between -3.535 and -3.1458).

\section{Histology}

Briefly, tissues (one tissue per patient) fixed in $10 \%$ neutral buffered formalin underwent a process of dehydration via a graded ethanol bath $(70 \%, 90 \%$, absolute ethanol), a clearing stage in xylene (Sigma) bath and, finally, were embedded in paraffin. Paraffin-embedded tissues were placed on ice at $-20^{\circ} \mathrm{C}$ overnight to improve the quality of cut sections. Tissue blocks were cut using a microtome (Accu-Cut ${ }^{\circledR}$ SRM $^{\mathrm{TM}}$ 200, Sakura, Netherlands) into $4 \mu \mathrm{m}$ sections. Five sections per patient were stained with hematoxylin \& eosin using an automated machine (Tissue-Tek ${ }^{\circledR}$ DRSTM 2000 Multiple slide stainer, Sakura). The histological changes were assessed qualitatively and described according to their histopathological features in response to metal debris exposure, as described previously. ${ }^{7}$
59 60 61 62 63 64 65 66 67 68 69 70 71 72 73 74 75 76 77 78 79 80 81 82 83 84 85 86 87 88 89 90 91 92 93 
TABLE I. Details of primers (Eurofins MWG Operon) used in the tissue samples analysis

\begin{tabular}{|c|c|c|}
\hline Gene & Oligo name & $\begin{array}{l}\text { Sequence }\left(5^{\prime}-3^{\prime}\right) \text {, forward }(f) \text {, } \\
\text { reverse }(r)\end{array}$ \\
\hline $18 S R N A$ & $18 S$ & $\begin{array}{l}\text { f GTAACCCGTTGAACCCCA } \\
\text { r CCATCCAATCGGTAGTAGCG }\end{array}$ \\
\hline HIF-1A & HIF- $1 \alpha$ & $\begin{array}{l}\text { f CACCTCTGGACTTGCCTTTC } \\
\text { r GGCTGCATCTCGAGACTTTT }\end{array}$ \\
\hline VEGF & VEGF & $\begin{array}{l}\text { f CTTGCCTTGCTGCTCTACCT } \\
\text { r CTGCATGGTGATGTTGGACT }\end{array}$ \\
\hline $\mathrm{HO}-1$ & HMOX1 & $\begin{array}{l}\text { f CСТTCTTCАССТTССССААС } \\
\text { r TGGССТСТTСТАТСАСССТC }\end{array}$ \\
\hline GLUT1 & SLC2A1 & $\begin{array}{l}\text { f TGGCATGGCGGGTTGT } \\
\text { r CCAGGGTAGCTGCTCCAGC }\end{array}$ \\
\hline$B N I P 3$ & BNIP3 & $\begin{array}{l}\text { f CTGCTGCTCTCTCATTTGCT } \\
\text { r ACCCCAGGATCTAACAGCTC }\end{array}$ \\
\hline $\operatorname{cox}-2$ & PTGS2 & $\begin{array}{l}\text { f TGTATGCCACAATCTGGCTG } \\
\text { r GAAGGGGATGCCAGTGATAG }\end{array}$ \\
\hline IL 1B & IL1B & $\begin{array}{l}\text { f GTCATTCGCTCCCACATTCT } \\
\text { r ACTTCTTGCCCCCTTTGAAT }\end{array}$ \\
\hline
\end{tabular}

\section{Data analysis}

Results are presented as scatter plots of each sample analyzed in a log scale of fold change (tissue gene expression) or a fold change (blood gene expression) relative to control. Data are shown as median \pm interquartile range. The normality of data was assessed using Shapiro-Wilk test. Datasets passing the normality tests were further assessed using a parametric independent 2-group $t$-test and Pearson correlation, and datasets failing the normality tests were analyzed using a nonparametric Mann-Whitney test and Kendall correlation (Supporting Information Table S1). The statistical analysis was performed using R Studio (Version 1.1.453) and graphs were prepared using GraphPad Prism (Version 6, USA). Correlation analysis assessed the strength $(r<0.29$ small association, $r>0.3<0.49$ a moderate association, $r>0.5$ a large association) and significance of the relationships between gene expressions. $P<0.05$ was considered statistically significant.

\section{RESULTS}

We analyzed molecular changes in the synovial tissue and the peripheral blood of patients with MoM hip implants. The activation of HIF pathway was investigated as a potential biomarker to predict implant failure.

\section{Histology of the synovial tissue}

As the initial stage, we compared the histopathology of the synovial tissues from PHR and control groups. We specifically looked at signs of inflammation (presence of lymphocytic infiltrates), fibrosis, local necrosis, and metallosis (presence of metallic debris products). This qualitative assessment was compared to the previously published histopathological features. ${ }^{7}$ The synovial tissues from the PHR group showed a presence of increased inflammatory cell infiltration around the area of the blood vessels and on the edge of the synovial membrane. Representative images are shown in Figure 2.
TABLE II. Details of KiCqStart primers used in blood analysis

\begin{tabular}{|c|c|c|}
\hline Gene & Oligo name & Sequence $\left(5^{\prime}-3^{\prime}\right)$, forward $(f)$, reverse $(r)$ \\
\hline \multirow[t]{2}{*}{ BACTIN } & ACTB & f GACGACATGGAGAAAATCTG \\
\hline & & r ATGATCTGGGTCATCTTCTC \\
\hline \multirow[t]{2}{*}{ GAPDH } & GAPDH & f ACAGTTGCCATGTAGACC \\
\hline & & r TTTTTTGGTTGAGCACAGG \\
\hline \multirow[t]{2}{*}{$B 2 M$} & B2M & f AAGGACTGGTCTTTCTATCTC \\
\hline & & r GATCCCACTTAACTATCTTGG \\
\hline \multirow[t]{2}{*}{ HPRT1 } & HPRT1 & f CTAATTATGGACAGGACTGAAC \\
\hline & & r AGCAAAGAATTTATAGCCCC \\
\hline \multirow[t]{2}{*}{ RPL13A } & RPL13A & f GTCTGAAGCCTACAAGAAAG \\
\hline & & r TGTCAATTTTCTTCTCCACG \\
\hline \multirow[t]{2}{*}{ HIF1A } & H1_HIF1A & f AAAATCTCATCCAAGAAGCC \\
\hline & & r AATGTTCCAАTTCCTACTGC \\
\hline \multirow[t]{2}{*}{ VEGF } & VEGFA & f AATGTGAATGCAGACCAAAG \\
\hline & & r GACTTATACCGGGATTTCTTG \\
\hline \multirow[t]{2}{*}{$\mathrm{HO}-1$} & HMOX1 & f CAACAAAGTGCAAGATTCTG \\
\hline & & r TGCATTCACATGGCATAAAG \\
\hline \multirow[t]{2}{*}{ GLUT1 } & St & f ACCTCAAATTTCATTGTGGG \\
\hline & & r GAAGATGAAGAACAGAACCAG \\
\hline \multirow[t]{4}{*}{ BNIP3 } & & f CAGTCTGAGGAAGATGATATTG \\
\hline & & r GTGTTTAAAGAGGAACTCCTTG \\
\hline & & f AAGCAGGCTAATACTGATAGG \\
\hline & & r TGTTGAAAAGTAGTTCTGGG \\
\hline \multirow{2}{*}{ IL1B } & IL1B & f CTAAACAGATGAAGTGCTCC \\
\hline & & r GGTCATTCTCCTGGAAGG \\
\hline \multirow[t]{2}{*}{ TNFA } & TNF & f AGGCAGTCAGATCATCTTC \\
\hline & & r TTATCTCTCAGCTCCACG \\
\hline \multirow{2}{*}{$N F K B$} & NFKB1 & f CACAAGGAGACATGAAACAG \\
\hline & & r CCCAGAGACCTCATAGTTG \\
\hline \multirow[t]{2}{*}{$I K B$} & NFKBIB & f CGATGAATACGACGACATTG \\
\hline & & r CCCAGAGACCTCATAGTTG \\
\hline \multirow[t]{2}{*}{ IL18 } & IL18 & f CCTTTAAGGAAATGAATCCTCC \\
\hline & & r CATCTTATTATCATGTCCTGGG \\
\hline \multirow[t]{2}{*}{ CASP1 } & CASP1 & f CAACTACAGAAGAGTTTGAGG \\
\hline & & r AACATTATCTGGTGTGGAAG \\
\hline \multirow[t]{2}{*}{ TLR1 } & TLR1 & f CССТACAAAAGGAATCTGTATC \\
\hline & & r TGCTAGTCATTTTGGAACAC \\
\hline \multirow[t]{2}{*}{ TLR2 } & TLR2 & f CTTTCAACTGGTAGTTGTGG \\
\hline & & r GGAATGGAGTTTAAAGATCCTG \\
\hline \multirow[t]{2}{*}{ TLR3 } & TLR3 & f AGATTCAAGGTACATCATGC \\
\hline & & r CAATTTATGACGAAAGGCAC \\
\hline \multirow[t]{2}{*}{$T L R 4$} & TLR4 & f GATTTATCCAGGTGTGAAATCC \\
\hline & & r TATTAAGGTAGAGAGGTGGC \\
\hline
\end{tabular}

In the MoM group, a lymphocytic infiltration was also observed around blood vessels and within the synovial tissue. In the MoM group, the lymphocytic infiltrate can be differentiated further into lymphocyte aggregates, synovitis and diffuse synovitis. A small perivascular lymphocyte aggregate can be seen in Figure 3c, where the lymphocytes form circles around the blood vessel. Furthermore, metallic wear debris can be seen within those aggregates, which is shown as a brown deposit.

On the other hand, a diffuse synovitis is observed in Figure $3 \mathrm{~b}$,d. Here, the lymphocytic infiltrate is not organized into follicles or aggregates but is spread throughout the tissue irregularly. The tissue itself has a fibrotic appearance. This fibrotic appearance most likely indicates a granulomatous inflammation, where sheets of histiocytes containing metallic debris are seen. 

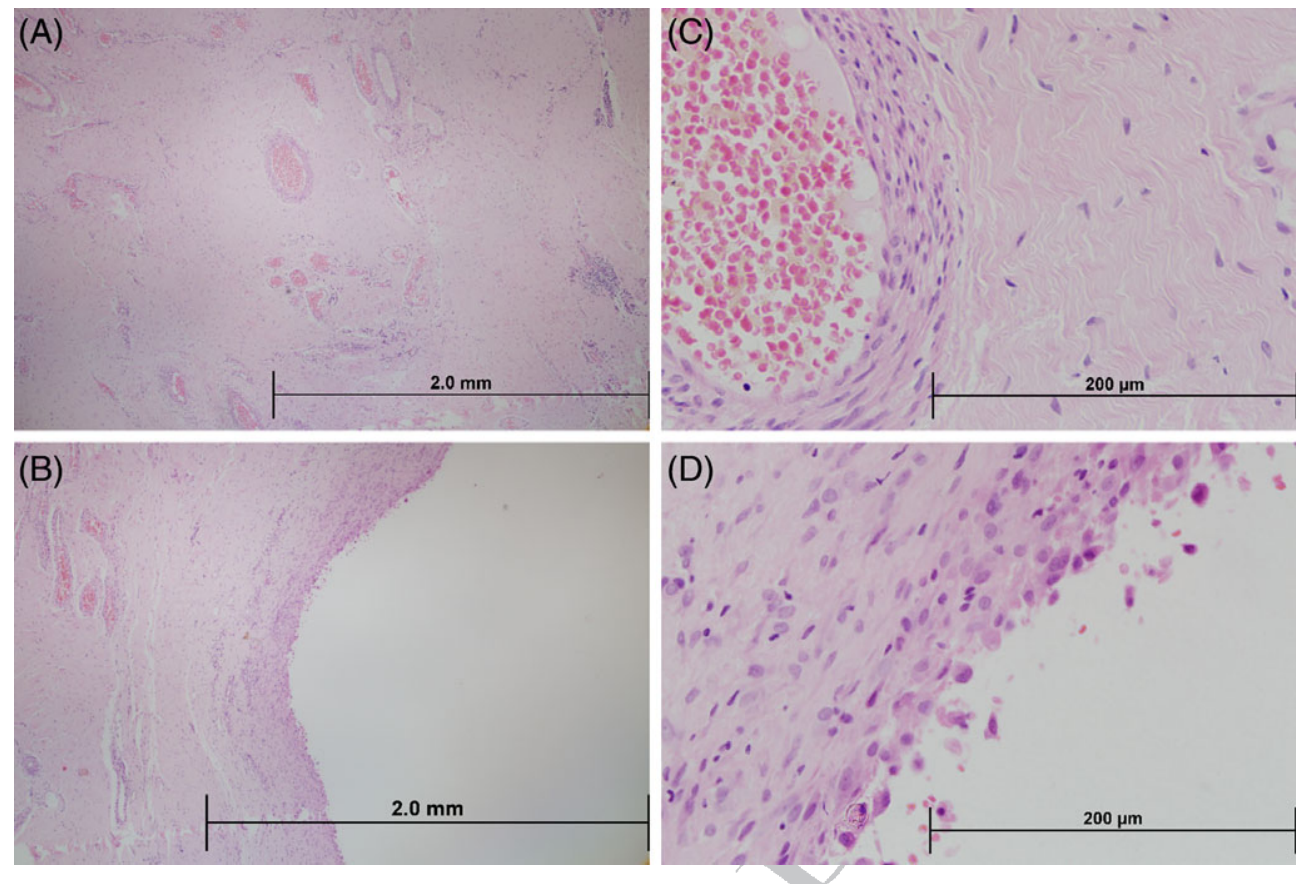

FIGURE 2. Synovial tissue from control patients. Hematoxylin and eosin (H\&E) staining of synovial tissue obtained from a primary hip surgery (PHR group) showing lymphocytic inflammation around the blood vessels $(a, c)$ and on the edge of the synovial membrane $(b, d)$.

\section{Analysis of gene expression changes in the synovial tissue}

The mRNA analysis of HIF target genes expression in the synovial tissue showed that patients with MoM implants have significantly increased mRNA expression (presented as $\log 2$ of relative fold change) of BNIP3, GLUT1, HO1, and VEGF
(Figure 4), comparing to patients from PHR group. No significant change was observed in the expression level of HIF1A mRNA. We further performed correlation analysis to determine whether there are significant correlations in the gene expressions between the tested mRNAs (Table III, Supporting Information Table S2). We found no significant
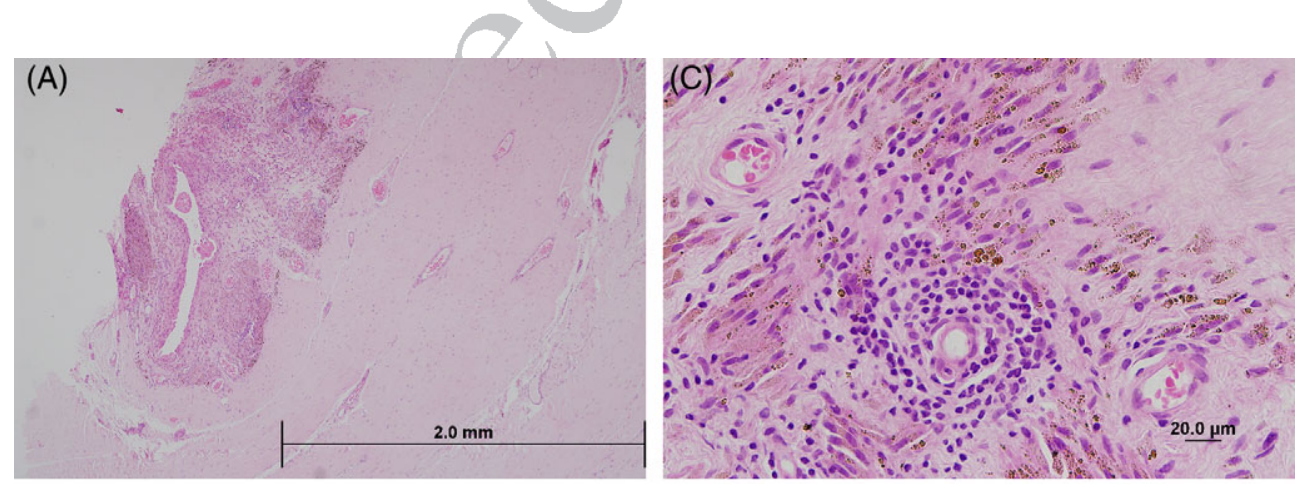

(B)

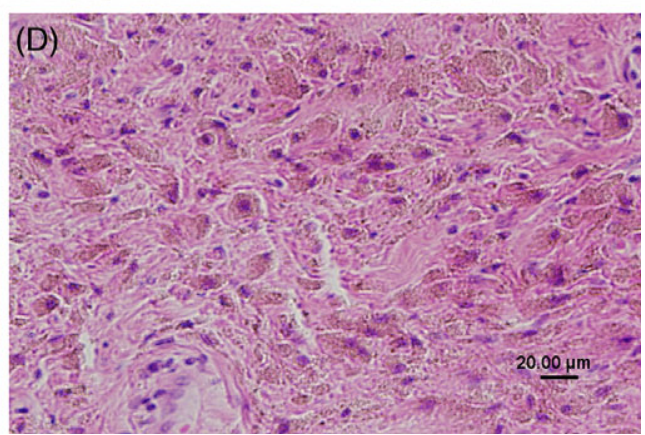

FIGURE 3. Synovial tissue from patients with a MoM hip implant. Hematoxylin and eosin (H\&E) staining of synovial tissue obtained from revision surgery of MoM hip implant. Increased inflammation with lymphoid aggregates (red bold square) and metallic debris (bold arrows) are present toward the synovial membrane $(a, c)$, while within the synovial tissue a fibrotic appearance is more prominent $(b, d)$. 
correlation between HIF1a mRNA expression and expression of the assessed HIF target genes in the PHR group, while there was a positive correlation between GLUT1 and BNIP3 mRNAs expression $(r=0.94, p<0.005)$. In the MoM group, the HIF1a mRNA expression was significantly correlated with HO1 mRNA expression $(r=0.77, p<0.005)$. HO1 mRNA expression was also significantly correlated with BNIP3 mRNA $(r=0.64, p<0.05)$ and VEGF mRNA expression $(r=0.58, p<0.05)$. In addition, VEGF mRNA expression was significantly correlated with GLUT1 mRNA expression $(r=0.63, p>0.05)$. The increased expression of HIF target genes and the significant correlations in the MoM group indicate a possible HIF response activation.

In addition, we investigated the inflammatory profile of the MoM tissues due to the observed inflammatory histopathology. Patients from the MoM group had significantly increased $I L 1 B$ mRNA level, but not the COX2 mRNA level (Figure 5). In the PHR group, we have not found any significant correlations between the expression of the inflammatory and HIF genes. In the MoM group, IL1b mRNA expression was significantly correlated with BNIP3 $(r=0.87$, $p<0.005), \operatorname{VEGF}(r=0.66, p>0.05)$, GLUT1 $(r=0.60$, $p<0.05), H O 1(r=0.58, p<0.05)$, and COX2 ( $r=-0.67$, $p<0.05)$ mRNAs expression.

\section{Analysis of gene expression changes in blood}

Next, we assessed blood samples from patients with MoM implants and compared them against healthy patients with no metal implants. The lack of samples from patients with failed MoM implant is the key limitations of our work, but by being able to measure changes in non-failed MoM, we investigated the presence of any markers that could indicate body response to MoM, and possibly in the future predict implant failure. To truly appreciate the gathered information, a follow-up study is required. However, in this article, we report that while the analysis of blood-derived mRNAs (presented as a relative fold change) showed no significant change in the expression levels of HIF1A mRNA or the HIF target genes mRNAs (GLUT1, BNIP3, HO1, or VEGF) (Figure. $6 \mathrm{a}-\mathrm{d}, \mathrm{f}$ ), a correlation analysis of the mRNAs expression levels (Table III, Supporting Information Table S2) showed significant correlations in both the control and MoM groups. In the control group, the mRNA expression level of HIF1A and BNIP3 ( $r=-0.64, p<0.05)$ was negatively correlated. In the MoM group, HIF1A mRNA expression was negatively correlated with both BNIP3 mRNA $(r=-0.5, p<0.05)$, and GLUT1 mRNA $(r=-0.71, p<0.005)$. BNIP3 mRNA expression was positively correlated with GLUT1 mRNA $(r=0.43, p<0.05)$.

While we did not detect any significant increase in the expression of HIF target genes when compared to the control group, we observed a significant increase in COX2 and H1B-mRNA levels. COX2 mRNA was increased from a median of $\sim 1.2$ fold change (range from 0.2 - to 2.9 fold change) in the control group to a median of $\sim 3.7$ fold change (range from 2.0 to 6.7 fold change) in the MoM group $(p=0.0002 \text {; Fig. } 7 \mathrm{e})_{1}$ while $L 1 B$ mRNA from a median of $\sim 1.0$ fold change (range from 0.6 to 1.7 fold
59 60 61 62 63 64 65 66 67 68 69 70 71 72 73 74 75 76 77 78 79 80 81 82 83 84 85 86 87 
change) in the control group to a median of $\sim 1.4$ fold change (range from 0.9 to 3.3 fold change) in the MoM group $(p=0.02$; Figure $6 \mathrm{e})$-Expression levels of a selection of other inflammatory genes (TNFA, IL18, CASPASE1, $N F K B$, and $I K B$ mRNA, Supporting Information Fig. S1) and genes encoding for Toll-like receptors (TLR1, TLR2, TLR3, and TLR4 mRNA, Supporting Information Fig. S2) were not significantly different.

Correlation analysis showed that in the control group, expression of COX2 mRNA was positively correlated with IL1B mRNA ( $r=0.73, p<0.05)$, while IL1B mRNA was also positively correlated with TLR2 mRNA $(r=0.89, p<0.005)$. In the MoM group, COX2 mRNA expression was positively correlated with expression of $\operatorname{VEGF}(r=0.55, p<0.005)$, IL1B $(r=0.78, p<0.001)$, and CASPASE1 $(r=0.66$, $p<0.005)$. IL1B mRNA expression was also positively correlated with VEGF $(r=0.37, p<0.05)$, COX2 $(r=0.78$, $p<0.001)$, and CASPASE1 $(r=0.64, p<0.001)$ mRNA expression.

Significant correlation results are presented in Table III with non-significant results in Supporting Information Table S2.

TABLE III. Correlation analysis: Highlighted significant correlations. Correlation analysis was performed using parametric Pearson correlation ${ }^{1}$ or nonparametric Kendall Correlation ${ }^{2}$. Strength of the relationships are listed in the table with $r<0.29$ small association, $r>0.3<0.49$ a moderate association, $r>0.5$ a large association. $* P<0.05$ was considered statistically significant; $* * p<0.005 ; * * * p<0.001$

\begin{tabular}{|c|c|c|c|c|}
\hline & Tissue & & Blood & \\
\hline Group & $\mathrm{PHR}^{1}$ & MoM $^{1}$ & $\begin{array}{l}\text { Control }^{1} \\
{ }^{2} \text { datasets including } \\
\text { HIF1A, GLUT1 }\end{array}$ & $\begin{array}{l}\text { MoM }^{1} \\
{ }^{2} \text { datasets including } \\
\quad B N I P 3, V E G F, T N F A, T L R 3\end{array}$ \\
\hline HIF1A versus $B N I P 3$ & 0.59 & 0.38 & $-0.64 *$ & $-0.50 *$ \\
\hline$H I F 1 A$ versus $I K B$ & - & - & $0.79 *$ & $0.61 *$ \\
\hline HIF1a versus $\mathrm{HO} 1$ & 0.18 & $0.77 * *$ & 0.14 & -0.13 \\
\hline HIF1A versus GLUT1 & 0.72 & 0.36 & 0.21 & $-0.71 * *$ \\
\hline HIF1A versus IL18 & - & - & 0.50 & $0.77 * * *$ \\
\hline HIF1A versus $T L R 1$ & - & - & 0.29 & $0.65^{*}$ \\
\hline HIF1A versus $T L R 4$ & - & - & 0.43 & $0.72 * *$ \\
\hline BNIP3 versus GLUT1 & $0.94 * *$ & 0.47 & 0.00 & $0.43^{*}$ \\
\hline$B N I P 3$ versus $I L 1 B$ & -0.01 & $0.87 * * *$ & -0.34 & 0.20 \\
\hline$B N I P 3$ versus $H O 1$ & -0.18 & $0.64 *$ & -0.23 & -0.03 \\
\hline$B N I P 3$ versus $I K B$ & - & - & -0.62 & $-0.58^{*}$ \\
\hline$B N I P 3$ versus $T L R 4$ & - & - & -0.64 & $-0.55^{* *}$ \\
\hline VEGF versus $I L 1 B$ & -0.59 & $0.66^{*}$ & 0.64 & $0.37 *$ \\
\hline VEGF versus GLUT1 & -0.03 & $0.63^{*}$ & 0.21 & -0.07 \\
\hline VEGF versus $C O X 2$ & 0.07 & -0.22 & 0.26 & $0.55^{* *}$ \\
\hline VEGF versus $T L R 3$ & - & - & 0.25 & $-0.47 *$ \\
\hline$I L 1 B$ versus $H O 1$ & -0.44 & $0.58 *$ & 0.40 & 0.40 \\
\hline$I L 1 B$ versus $C O X 2$ & 0.65 & $-0.67 *$ & $0.73^{*}$ & $0.78 * * *$ \\
\hline$I L 1 B$ versus $G L U T 1$ & -0.16 & $0.60 *$ & -0.07 & 0.21 \\
\hline$I L 1 B$ versus $T L R 2$ & - & - & $0.89 * *$ & -0.15 \\
\hline IL1B versus $C A S P A S E 1$ & - & - & 0.52 & $0.64 *$ \\
\hline$H O 1$ versus $C O X 2$ & -0.37 & $-0.66^{*}$ & 0.08 & 0.18 \\
\hline HO1 versus GLUT1 & 0.12 & $0.58 *$ & -0.50 & 0.00 \\
\hline HO1 versus CASPASE1 & - & - & $0.78 *$ & $0.58 *$ \\
\hline HO1 versus $T L R 1$ & - & - & $0.79 *$ & -0.01 \\
\hline COX2 versus CASPASE 1 & - & - & 0.12 & $0.66^{* *}$ \\
\hline GLUT1 versus TNFA & - & - & 0.07 & $0.47 *$ \\
\hline GLUT1 versus $I L 18$ & - & - & -0.14 & $-0.73^{* * *}$ \\
\hline GLUT1 versus $I K B$ & - & - & 0.00 & $-0.70 * *$ \\
\hline GLUT1 versus TLR4 & - & - & -0.07 & $-0.69 * *$ \\
\hline TNFA versus $N F K B$ & - & - & 0.71 & $-0.38 *$ \\
\hline CASPASE 1 versus TLR1 & - & - & $0.85 *$ & -0.17 \\
\hline IL18 versus $N F K B$ & - & - & 0.62 & $0.58 *$ \\
\hline$I L 18$ versus $I K B$ & - & - & $0.80 *$ & 0.48 \\
\hline IL18 versus $T L R 1$ & - & - & 0.50 & $0.69 * *$ \\
\hline IL 18 versus $T L R 2$ & - & - & -0.14 & $0.53 *$ \\
\hline IL 18 versus TLR4 & - & - & 0.48 & $0.65^{*}$ \\
\hline$I K B$ versus $T L R 1$ & - & - & 0.45 & $0.53^{*}$ \\
\hline$I K B$ versus $T L R 2$ & - & - & -0.19 & $0.52 *$ \\
\hline$I K B$ versus $T L R 4$ & - & - & 0.61 & $0.80 * *$ \\
\hline$T L R 1$ versus $T L R 2$ & - & - & 0.59 & $0.60 *$ \\
\hline$T L R 1$ versus $T L R 4$ & - & - & $0.89 * *$ & $0.73 * * *$ \\
\hline$T L R 2$ versus $T L R 4$ & - & - & 0.59 & $0.61 *$ \\
\hline
\end{tabular}

59 60 61 62 63 64 65 66 67 68 69 70 


\section{DISCUSSION}

Hip implants can provide a life-changing treatment and improve patients' mobility and independence. However, medical implants failures do occur and can endanger patients' health and cause a burden to the healthcare systems worldwide. There is a need for an improved medical implant governance, enhanced functionality and compatibility, which could be addressed by monitoring biological responses. Our study aimed to identify markers for ARMD in patients with MoM implants. It consisted of non-overlapping patients with failed MoM (tissue analysis) and non-failed MoM (blood analysis), which is a major limitation of the reported results. The candidate markers included the HIF target genes due to the previous reports of HIF pathway activation by metal debris. We found increased expression of HIF target genes in the synovial tissue from MoM patients supporting our hypothesis that HIF activation could be an indicator of MoM failure. However, these promising results are limited by the small number of patients and lack of tissues from multiple sites. To overcome these limitations and to be able to identify significant and relevant changes in the tissues, the tissue samples were cut and divided into separate triplicates (RNA investigation) to provide reproducible results. While analysis of blood samples from MoM patients has not revealed any significant changes in the expression levels of the HIF target markers when compared to the control group, we found significant correlations between the expression of HIF target genes, and in the inflammatory markers.

\section{HIF pathway activation in MoM patients}

An increase in HIF-1 $\alpha$ protein was previously reported in the MoM peri-implant tissue when compared to MoP implant. ${ }^{8}$ In our study, we have not detected increased levels of HIF1A mRNA in the MoM patients. While HIF-1 $\alpha$ protein is upregulated during hypoxic stress due to decreased HIF$1 \alpha$ protein degradation, ${ }^{11}$ the translational efficiency of HIF1A mRNA does not change, ${ }^{12}$ as it is not transcriptionally regulated. ${ }^{13}$ Hence, the levels of mRNA are not expected to significantly change during hypoxic stress, which could explain the lack of changes in HIF1A mRNA in our study.
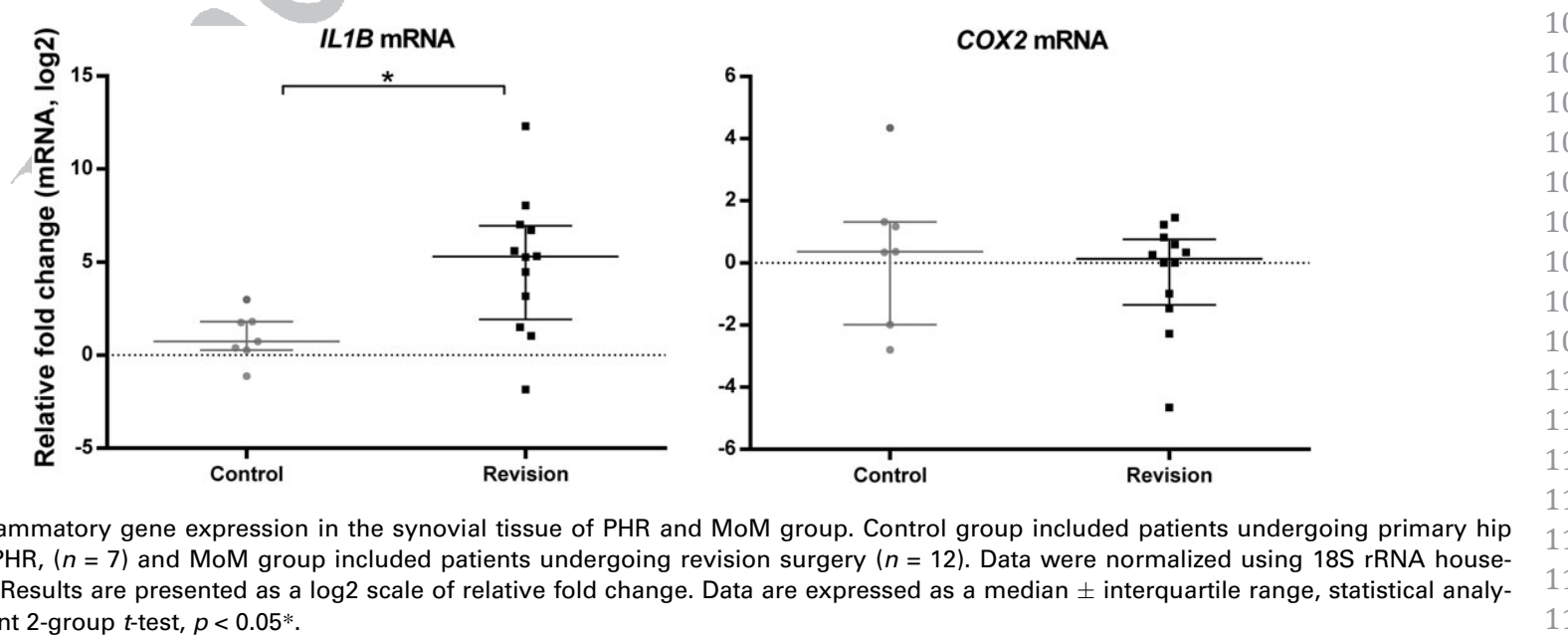

Nonetheless, the activation of HIF pathway was indicated by an increase in the expression level of HIF target genes, including BNIP3, HO1, VEGF, and GLUT1 (Figure 4) in the MoM group. HIF1a mRNA expression was also correlated with HO1 mRNA expression. Synovial tissues from patients with rheumatoid arthritis and osteoarthritis had increased expression of HIF-1 $\alpha$ protein $^{14}$ and increased expression of HIF target, BNIP3 protein. ${ }^{15}$ This suggest that our PHR group could have increased levels HIF-related mRNAs due to their underlying conditions, while also indicating that the significant changes in the MoM group indicate HIF pathway activation most likely due to the MoM debris and not due to any other underlying condition. This is the first time that this has been reported in periprosthetic tissues from MoM patients.

\section{Histopathology of the synovial tissues}

While the number of tissues for histopathological assessment was limited ( 1 per patient), we identified signs of lymphocytic response in the control group around blood vessels and the edge of the synovial membrane. Small perivascular lymphocyte aggregates were also present in the MoM group; however, here a presence of diffuse synovitis was also noticed. Within the inflamed areas metallic wear debris was present (brown deposits) (Figure 3). Similar histopathological changes were observed previously. ${ }^{7}$ Aseptic lymphocytic vasculitis-associated lesion (ALVAL) score, characterized by a lymphocyte-dominated reaction in the periprosthetic tissue, was shown to be associated with pain and suspected metal sensitivity in MoM patients (average ALVAL score $8.5 \pm 1.4$ ), while those revised for high MoM wear showed a lower ALVAL score (average $3.6 \pm 2.5$ ) and higher presence of macrophages and metal particles. ${ }^{16}$ In another study of 119 MoM hip implants, the magnitude of wear had no positive correlation with ALVAL score or pseudotumor formation. ${ }^{17}$ These findings indicate that there are different responses among patients with MoM implants, which are either lymphocyte or macrophage dominated, or a mixture of both types. ${ }^{18}$ This differential response could indicate patients' predisposition or sensitivity to metal components. This highlights the 
difficulties in monitoring implants longevity and in detecting early implant failure.

\section{Inflammatory changes in the synovial tissues}

Circulating cytokine levels are often reported to be increased in patients with MoM, while cytokine levels in the tissue surrounding the MoM implant, such as TNF- $\alpha$, were shown to be increased at a similar level to a tissue surrounding MoP implant. ${ }^{19}$ In the current study, we confirmed the presence of inflammatory markers in the MoM tissue, with a significant increase in IL1B mRNA (Figure 5). IL-1 $\beta$ is also upregulated in cartilage and synovium of osteoarthritis patients. ${ }^{20}$ In our study, we showed that, when compared to control patients undergoing PHR, there is a further upregulation of $I L 1 B$ mRNA. This indicates a possible role of IL-1 $\beta$ signaling in the failure of MoM implants, which was previously associated with lymphocyte-dominated tissue response in failed small-diameter MoM total hip arthroplasty. ${ }^{21}$ We also found a positive correlation between IL1B mRNA and BNIP3/VEGF/ COX2/HO1/GLUT1 mRNAs expression. Previous in vitro study showed that $I L 1 B$ mRNA goes through a phase of early increase, followed by a continuous decreased expression. For the sustained late expression, $I L 1 B$ mRNA is dependent on HIF- $1 \alpha$ and CCAAT-enhancer-binding proteins $\beta .^{22}$ Increase in HIF- $1 \alpha$ protein in the tissue could lead to an enhanced expression of $I L 1 B$ mRNA. However, the translational activity of this mRNA could be affected, and hence, COX2 mRNA was not significantly induced.

These results suggest that markers for HIF activation could be used as tissue biomarkers of ARMD.
Changes in blood in MoM patients

In the next stage, we collected blood samples from nonoverlapping group of nonfailed MoM patients to identify any changes in the mRNA levels related to HIF pathway activation or inflammation. While having samples from failed MoM would be more relatable to the tissue samples, the analysis of nonfailed MoM could still give us answer to any early changes that could predict future failure. Further study using larger cohort of nonfailed and failed MoM samples should be performed.

The control group included blood from healthy volunteers (no underlying inflammatory conditions). There was no significant difference in the mRNA expression of HIF target genes (Figure 6) or TLR genes (Supporting Information Fig. S2) between the two groups. Both in the control and MoM groups, HIF1A mRNA expression was negatively correlated with BNIP3 mRNA. In the MoM group, HIF1A mRNA was also negatively correlated with GLUT1 mRNA. Higher expressions of BNIP3/GLUT1 mRNA during lower expressions of HIF1A mRNA could indicate a negative feedback during HIF activation; however, this should be further investigated. A significant increase was observed in COX2 mRNA expression in the MoM group when compared to the control group. This increase could be originating from any underlying condition of MoM patients, such as arthritis, ${ }^{23}$ or due to the MoM debris-specific response. To elucidate this, we performed a correlation analysis. In the control group, we found correlations between COX2 and $I L 1 B$ mRNA expressions. In the MoM group, COX2 mRNA expression was also correlated with $I L 1 B$, and additionally with $V E G F$ and CASPASE1 mRNAs. This is in contrary to the results found in the MoM
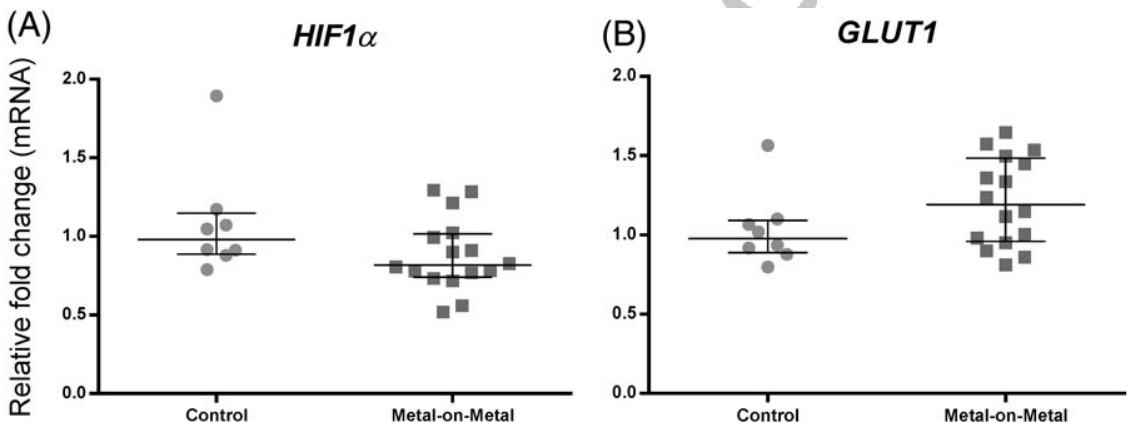

(D)

HO-1

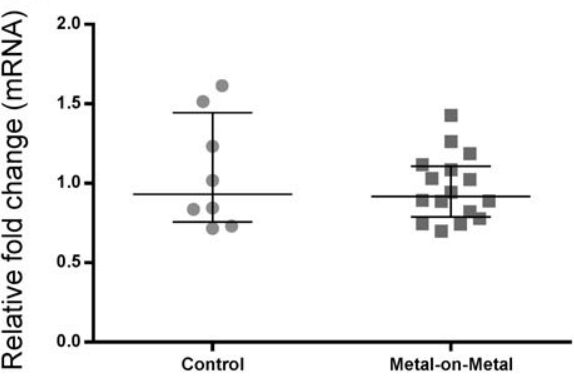

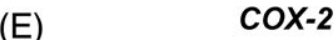

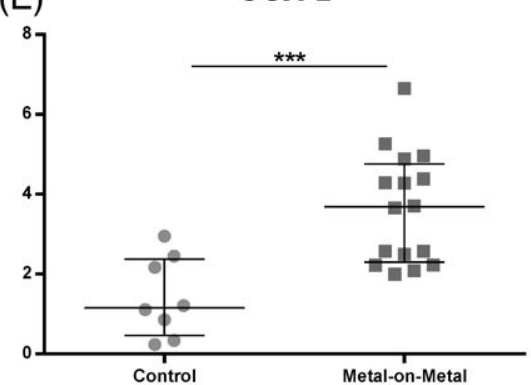

(C)

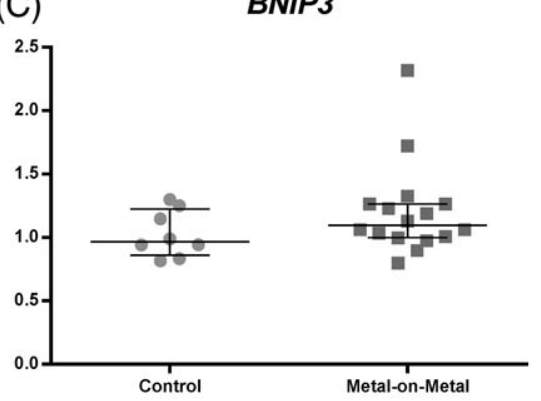

(F)

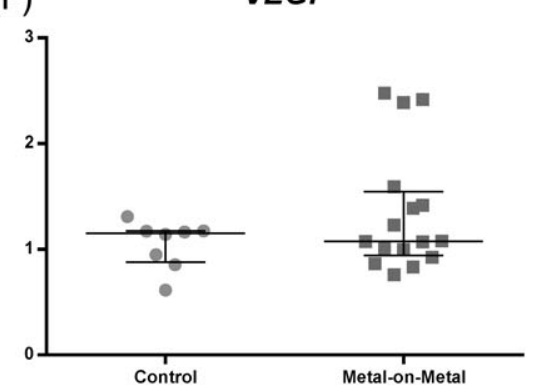

59 60 61 62 63 64 65 66 67 68

FIGURE 6. HIF target gene expression in blood samples from control and MoM groups. Control group included healthy volunteers $(n=8)$ and the test MoM group included patients with $\operatorname{MoM}(n=16)$. Data were normalized using housekeeping genes ( $\beta$-actin, GAPDH, B2M, HPRT1, RPL13A). Results are presented as a relative fold change. Data are expressed as a median \pm interquartile range, statistical analysis: independent 2-group $t$ test and Mann-Whitney test, $p<0.001 * * *$. 
tissues, and could indicate an early activation of $I L 1 B$, rather than the prolonged response in the synovial membrane. Caspase 1 is responsible for the processing and secretion of IL$1 \beta$ and IL-18, and the induction of $\operatorname{COX} 2{ }^{24}$ This indicates a possible activation of inflammatory pathway observed in the blood, but further proteomics evidence is required. The correlation with VEGF mRNA could indicate a pro-angiogenic response $^{25}$ that could be initiated by the HIF activation. In addition, we measured the correlation with HIF1a mRNA expression. In the control and MoM groups, HIF1a mRNA expression was positively correlated with IKB mRNA expression. In the MoM group, we found further correlations with IL18, TLR1, and TLR4 mRNAs. TLR4 was shown previously to influence HIF-1 $\alpha$ through a redox-dependent mechanism, ${ }^{26}$ which could explain the correlation observed in the MoM group. The correlation of HIF1a mRNA with TLR1 mRNA expression indicates another association between the two pathways in the cellular immune response. The correlation with IL18 mRNA in the MoM group could indicate an inflammatory pathway activation related to the COX2/CASPASE1, while indicating that it is also stimulated by the HIF pathway activation. The lack of significant changes in the HIF target gene expression detected in the blood samples between the MoM and control groups could be due to a very early response to the implant. Therefore, any putative changes might only be detectable in a situation when the MoM is failing, or patients are complaining of pain or other adverse responses. Previously no significant difference in HIF-1 $\alpha$ protein was reported in the serum of MoM when compared to presurgery group (osteoarthritis group), and no correlation between circulating $\mathrm{Cr}$ and Co levels and HIF-1 $\alpha$ were found. ${ }^{27}$ Furthermore, no difference was found in the circulating HO-1 protein or mRNA level in a MoM group when compared to a non-MoM group ${ }^{28}$ This further suggests that a significant HIF response could occur later in the pathology when adverse tissue response occurs. However, the observed correlations in this study suggest a possible early detection of the adverse response. To fully understand the mechanism of this early adverse response and to identify early markers, an investigation with a larger cohort of patients is required.

\section{CONCLUSION}

Histological assessment of synovial tissue showed presence of lymphocyte aggregates, diffuse synovitis, and presence of wear debris. This agrees with previous reports in the literature and indicates that any changes in the molecular markers could be a useful indicator of the pathogenic mechanisms. Further analysis of the synovial tissue highlighted increased expression of HIF target genes (e.g., BNIP3 and HO1) in MoM patients when compared to the control group (PHR). While this supports the hypothesis that there is an in vivo HIF pathway activation in response to MoM wear debris suggesting possible tissue biomarkers for ARMD, there was a variation in the gene expression between patients possibly related to the clinical performance or patient-specific factors, requiring a larger study to further support the possible tissue biomarkers.

The blood analysis from nonfailed MoM patients did not show any significant changes in the HIF target genes or inflammatory genes between a control and MoM groups, apart from a significant increase in COX2 mRNA. However, in the MoM group, we identified a significant correlation between HIF1A mRNA expression and GLUT1/BNIP3 mRNAs, indicating response activation, and possible identification of biomarkers. To confirm this, a further longitudinal assessment should be performed comparing blood analysis of wellfunctioning and failing MoM implants.

\section{ACKNOWLEDGMENTS}

Authors would like to thank surgeons, nurses, theater staff and phlebotomists who helped to obtain the samples. This study was funded by the Innovate UK (previously Technology Strategy Board) as part of BERTI project (Grant number 101005).

\section{AUTHOR CONTRIBUTION}

AN, AH, and TDT conceived and designed the experiments, AN performed the experiments, analyzed the data, and wrote the manuscript. AN, AH, and TDT edited and approved the final submitted version.

\section{REFERENCES}

1. Hasegawa M, Yoshida K, Wakabayashi H, Sudo A. Prevalence of adverse reactions to metal debris following metal-on-metal THA. Orthopedics 2013;36(5):e606-e612.

2. Ricciardi BF, Nocon AA, Jerabek SA, Wilner G, Kaplowitz E, Goldring SR, Purdue PE, Perino G. Histopathological characterization of corrosion product associated adverse local tissue reaction in hip implants: a study of 285 cases. BMC Clin Pathol. 2016;16:3.

3. Bosker BH, Ettema HB, van Rossum M, Boomsma MF, Kollen BJ, Maas M, Verheyen CC. Pseudotumor formation and serum ions after large head metal-on-metal stemmed total hip replacement. Risk factors, time course and revisions in 706 hips. Arch Orthop Trauma Surg 2015;135(3):417-425.

4. Chen Z, Wang Z, Wang Q, Cui W, Liu F, Fan W. Changes in early serum metal ion levels and impact on liver, kidney, and immune markers following metal-on-metal total hip arthroplasty. J Arthroplasty 2014;29(3):612-616.

5. Hallab NJ, Anderson S, Caicedo M, Skipor A, Campbell P, Jacobs JJ. Immune responses correlate with serum-metal in metalon-metal hip arthroplasty. J Arthroplasty 2014;19(8):88-93.

6. Drynda A, Singh G, Buchhorn GH, Awiszus F, Ruetschi M, Feuerstein $\mathrm{B}$, Kliche $\mathrm{S}$, Lohmann $\mathrm{CH}$. Metallic wear debris may regulate CXCR4 expression in vitro and in vivo. J Biomed Mater Res A 2015;103(6):1940-1948.

7. Natu S, Sidaginamale RP, Gandhi J, Langton DJ, Nargol AV. Adverse reactions to metal debris: histopathological features of periprosthetic soft tissue reactions seen in association with failed metal on metal hip arthroplasties. J Clin Pathol 2012;65(5):409-418.

8. Samelko L, Caicedo MS, Lim SJ, Della-Valle C, Jacobs J, Hallab NJ. Cobalt-alloy implant debris induce HIF-1alpha hypoxia associated responses: a mechanism for metal-specific orthopedic implant failure. PLoS One 2013;8(6):e67127.

9. Nyga A, Hart A, Tetley T. Importance of the HIF pathway in cobalt nanoparticle-induced cytotoxicity and inflammation in human macrophages. Nanotoxicology 2015;9(7):905-917.

10. Livak KJ, Schmittgen TD. Analysis of relative gene expression data using real-time quantitative PCR and the $2^{-\Delta \Delta C T}$ method. Methods 2011;25(4):402-408. 
11. Wang GL, Jiang $B H$, Rue EA, Semenza GL. Hypoxia-inducible factor 1 is a basic-helix-loop-helix-PAS heterodimer regulated by cellular O2 tension. Proc Natl Acad Sci U S A 1995;92(12):5510-5514.

12. Young RM, Wang SJ, Gordan JD, Ji X, Liebhaber SA, Simon MC Hypoxia-mediated selective mRNA translation by an internal ribosome entry site-independent mechanism. J Biol Chem 2008; 283(24):16309-16319.

13. Wenger RH, Kvietikova I, Rolfs A, Gassmann M, Marti HH. Hypoxiainducible factor- 1 alpha is regulated at the post-mRNA level. Kidney Int 1997;51(2):560-563.

14. Giatromanolaki A, Sivridis E, Maltezos E, Athanassou N Papazoglou D, Gatter KC, Harris AL, Koukourakis MI. Upregulated hypoxia inducible factor-1alpha and -2alpha pathway in rheumatoid arthritis and osteoarthritis. Arthritis Res Ther 2003;5(4):R193-R201.

15. Kammouni W, Wong K, Ma G, Firestein GS, Gibson SB, ElGabalawy HS. Regulation of apoptosis in fibroblast-like synoviocytes by the hypoxia-induced Bcl-2 family member Bcl-2/adenovirus E1B 19-kd protein-interacting protein 3. Arthritis Rheum. 2007 56(9):2854-2863.

16. Campbell P, Ebramzadeh E, Nelson S, Takamura K, De Smet K, Amstutz HC. Histological features of pseudotumor-like tissues from metal-on-metal hips. Clin Orthop Relat Res 2010;468(9):2321-2327.

17. Ebramzadeh E, Campbell P, Tan TL, Nelson SD, Sangiorgio SN. Can wear explain the histological variation around metal-on-metal total hips? Clin Orthop Relat Res 2015;473(2):487-494.

18. Berstock JR, Baker RP, Bannister GC, Case CP. Histology of failed metal-on-metal hip arthroplasty; three distinct sub-types. Hip Int 2014;24(3):243-248.

19. Campbell PA, Wang M, Amstutz HC, Goodman SB. Positive cytokine production in failed metal-on-metal total hip replacements. Acta Orthop Scand 2002;73(5):506-512.

20. Saha N, Moldovan F, Tardif G, Pelletier JP, Cloutier JM, MartelPelletier J. Interleukin-1beta-converting enzyme/caspase-1 in human osteoarthritic tissues: localization and role in the maturation of interleukin-1beta and interleukin-18. Arthritis Rheum. 1999;42(8): 1577-1587.

21. Singh G, Neuchtern JV, Meyer H, Fiedler GM, Awiszus F, JunkJantsch S, Bruegel M, Pflueger G, Lohmann CH. Particle characterisation and cytokine expression in failed small-diameter metal-on-metal total hip arthroplasties. Bone Joint J 2015;97(B7): 917-923.

22. Pulugulla SH, Adamik J, Grillini AN, Galson DL, Auron PE. Specific transcription factors distinctly regulate kinetics of $I L 1 B$ and $T N F$ gene expression. J Immunol 2016;196:189.14.

23. Woods JM, Mogollon A, Amin MA, Martinez RJ, Koch AE. The role of COX-2 in angiogenesis and rheumatoid arthritis. Exp Mol Pathol 2003:74(3):282-290.

24. Cunha TM, Talbot J, Pinto LG, Vieira SM, Souza GR, Guerrero AT, Sonego F Jr, Verri WA, Zamboni DS, Ferreira SH, Cunha FQ. Caspase-1 is involved in the genesis of inflammatory hypernociception by contributing to peripheral IL-1 $\beta$ maturation. Mol Pain 2010;6:63.

25. Wu G, Luo J, Rana JS, Laham R, Sellke FW, Li J. Involvement of COX-2 in VEGF-induced angiogenesis via $P 38$ and JNK pathways in vascular endothelial cells. Cardiovasc Res 2006;69(2):512-519.

26. Sumbayev VV. LPS-induced toll-like receptor 4 signalling triggers cross-talk of apoptosis signal regulating kinase 1 (ASK1) and HIF1alpha protein. FEBS Lett 2008;582:319-326.

27. Savarino L, Fotia C, Roncuzzi L, Greco M, Cadossi M, Baldini N, Giannini S. Does chronic raise of metal ion levels induce oxidative DNA damage and hypoxia-like response in patients with metal-onmetal hip resurfacing? J Biomed Mater Res B Appl Biomater 2017; 105(2):460-466.

28. Beraudi A, Bianconi $E$, Catalani S, Canaider S, De Pasquale D, Apostoli P, Bordini B, Stea S, Toni A, Facchin F. In vivo response of heme-oxygenase-1 to metal ions released from metal-on-metal hip prostheses. Mol Med Rep 2016;14(1):474-480. 